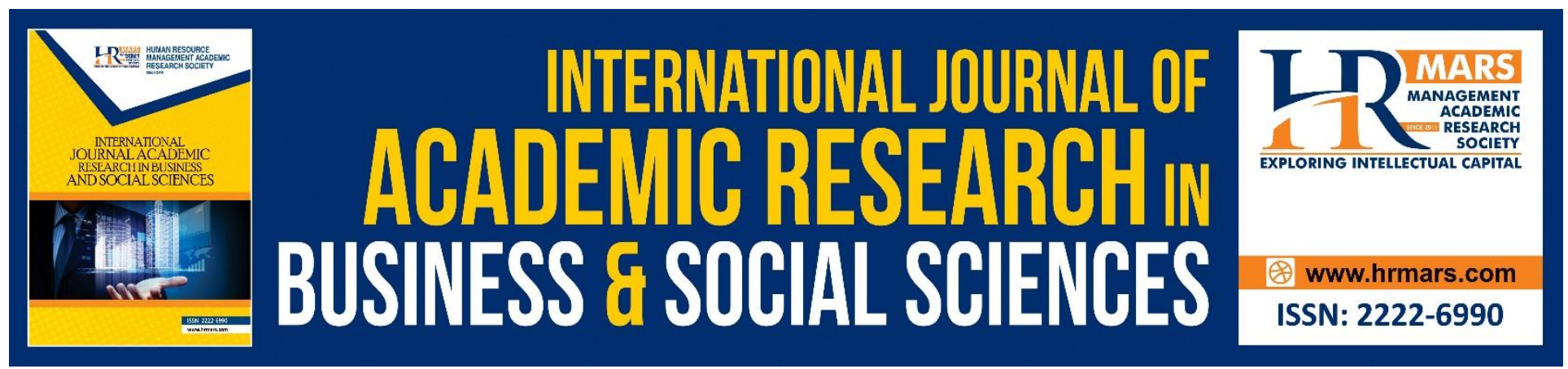

\title{
The Effect of Trust and Satisfaction on Customer Loyalty in Online Shop: Case of C2C E-Commerce in Indonesia
}

\author{
Emi Rahayu, Fakhri Fauzan, Hendrianto Wijaya, Willy Gunadi
}

To Link this Article: http://dx.doi.org/10.6007/IJARBSS/v10-i8/7619

DOI:10.6007/IJARBSS/v10-i8/7619

Received: 13 May 2020, Revised: 15 June 2020, Accepted: 20 July 2020

Published Online: 21 August 2020

In-Text Citation: (Rahayu, Fauzan, Wijaya, \& Gunadi, 2020)

To Cite this Article: Rahayu, E., Fauzan, F., Wijaya, H., \& Gunadi, W. (2020). The Effect of Trust and Satisfaction on Customer Loyalty in Online Shop: Case of C2C E-Commerce in Indonesia. International Journal of Academic Research in Business and Socail Sciences. 10(8), 699-709.

Copyright: (C) 2020 The Author(s)

Published by Human Resource Management Academic Research Society (www.hrmars.com)

This article is published under the Creative Commons Attribution (CC BY 4.0) license. Anyone may reproduce, distribute, translate and create derivative works of this article (for both commercial and non-commercial purposes), subject to full attribution to the original publication and authors. The full terms of this license may be seen

at: http://creativecommons.org/licences/by/4.0/legalcode

Vol. 10, No. 8, 2020, Pg. 699 - 709

http://hrmars.com/index.php/pages/detail/IJARBSS

JOURNAL HOMEPAGE

Full Terms \& Conditions of access and use can be found at http://hrmars.com/index.php/pages/detail/publication-ethics 


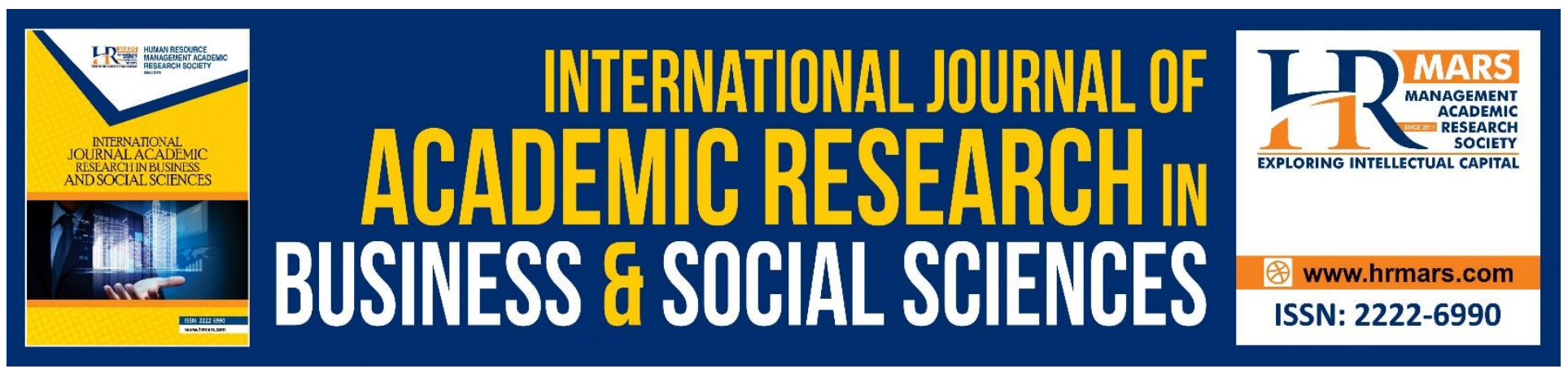

\title{
The Effect of Trust and Satisfaction on Customer Loyalty in Online Shop: Case of C2C E-Commerce in Indonesia
}

\author{
Emi Rahayu, Fakhri Fauzan, Hendrianto Wijaya, Willy Gunadi \\ Business Management, BINUS Business School Master Program, Bina Nusantara University \\ Jakarta, Indonesia \\ Email: emirahayu.er@gmai.com
}

\begin{abstract}
The purpose of this study is to identify user interface quality, information quality, perceived security, perceived privacy, and online customer review as a factor affecting customer trust and customer satisfaction in online business, especially in C2C e-commerce platform in Indonesia. This study also analyzes the effect of customer trust and customer satisfaction as key factors influencing customer loyalty. A quantitative approach has been employed. The data collection using online questionnaire in 206 respondents and measurement using Likert scale. For the purpose of data analysis, Partial Square Structural Equation Modeling (PLS-SEM) has been adopted. This study found that user interface quality and information quality have positive effect on customer trust and customer satisfaction. This study also found that customer satisfaction influencing customer loyalty significantly in Shopee. This study suggests that Shopee as an e-commerce in Indonesia must focus on their customer trust and customer satisfaction strategies by increasing the quality of user interface quality and information quality to maintain the loyalty of their customers.
\end{abstract}

Keywords: Shopee, E-Commerce, Customer Loyalty, Online Customer Review.

\section{Introduction}

Customer loyalty is a major goal in the marketing strategy of a business and provides favorable results (Kotler, 2010). (MittaL \& Sheth, 2004) stated that customer loyalty as a consumer commitment to a brand, store or supplier based on positive traits and is reflected in consistent repeat purchases. Loyal customers are more likely to discuss past service experiences positively than nonloyal customers, creating a potential for word-of-mouth advertising at no extra cost to the service provider (Shoemaker \& Lewis, 1999). From a seller's perspective, customer loyalty has been recognized as a key path to profitability. The high cost of acquiring customers renders many customer relationships unprofitable during early transactions (Reicheld \& Sasser, 1990). Customer loyalty can increase the company profits because loyal customers will be willing to spend higher costs for the 
products offered by a brand, store or supplier and be more tolerant if they get some problems from products or services they have purchased. In e-commerce industry, the difficulty of attracting customers through internet media and making them can't turn to other e-commerce makes customer loyalty becomes very valuable (Zhang, Dixit \& Friedmann, 2010).

The internet has become an essential business platform for trading, distributing and selling products between organizations, among organizations and consumers, and even between consumers. This has brought e-commerce to an entirely new level (Barnes \& Vidgen, 2000). The development of e-commerce has spread to various countries, such as the United States, and some countries in ASEAN. The growth of e-commerce in ASEAN countries, especially Indonesia has grown rapidly with the number of internet users reached 143.26 million (Kiminfo, 2018). Therefore, the development of e-commerce and transaction value made by internet users in Indonesia is predicted to increase every year. In Indonesia, the most popular online business category in Indonesia is ecommerce with platform consumer to consumer (C2C). Based on the ranking of the number of visitors per month in platform consumer to consumer (C2C), the top five are Tokopedia, Bukalapak, Shopee, Jakmall, and Tees.

This research is focusing on $\mathrm{C} 2 \mathrm{C}$ e-commerce that has rapid growth in Indonesia. Shopee is a leading e-commerce platform in Southeast Asia, China, and Taiwan. Shopee is a company under SEA Group, was first launched in Singapore in 2015, Shopee has expanded reach to Indonesia, Malaysia, Thailand, Philippines, Vietnam, and Taiwan. Based on updated data (Iprice, 2018), in first quarter 2018, Shopee dominates mobile apps by maintaining its position in the first rank as the most popular apps on Android and iOS platform. The CEO of SEA Group showed the growth of Shopee in first quarter 2018 around 111 million gross order, which has around 217 percent year over year growth.

Online reviews have become an important information source that allow consumers to search for detailed and reliable information by sharing past consumption experiences (Gretzel, et al., 2011; Yoo

\& Gretzel, 2008). Based on the following research, variables that use to explain customer loyalty are user interface quality, information quality, perceived privacy, and perceived security. Online review in online business is extremely important, because $67 \%$ of consumers are influenced by online reviews (Hardy, 2018). Online review shows that higher review make top of the search result page. Therefore, this research adds the online customer review factor as a research gap from pre-existing research. The purpose of this study is to identify user interface quality, information quality, perceived security, perceived privacy, and online customer review as a factor affecting the trust and satisfaction of the e-commerce users toward e-loyalty.

\section{Literature Review and Hypothesis Development}

The user interface of the website represent how the atmosphere of the website, if the looks of its website quite interest, easy to use, and looks neat, buyers will think if this website is a trustworthy shop (Koufaris \& Hampton-Sosa, 2004). The quality of a user interface is expected to affect trust directly (Gummerus et al., 2004). Similarly, the ease of navigation, interface design, and user guidance affect consumer establishment of trust (Roy, Dewit \& Aubert, 2001). The quality of the user interface affects the customer satisfaction directly, since it provides physical evidence of the service provider's competence as well as facilitating effortless use of the service (Park \& Kim, 2003). This study establishes the following hypothesis:

H1a: User interface quality has positive effect customer trust

H1b: User interface quality has positive effect customer satisfaction 
INTERNATIONAL JOURNAL OF ACADEMIC RESEARCH IN BUSINESS AND SOCIAL SCIENCES Vol. 10, No. 8, 2020, E-ISSN: 2222-6990 @ 2020 HRMARS

Information quality plays an important role in enabling consumers to buy a product or service without making direct contact with the products or services from an e-commerce website (Todd, 2005; Kim \& Lennon, 2008). Recent research has confirmed that information quality influences consumer trust; in particular, the website content and design affect consumer trust (Floh \& Treiblmaier, 2006; Mithas et al., 2006). Website content quality has been argued to be an antecedent of customer trust (McKnight, Choudhury \& Kacmar, 2002) and another study also found that the information quality, as one of the characteristics of website quality and has positive effect on customer satisfaction (Sadeh et al., 2011). This study establishes the following hypothesis:

$\mathrm{H} 2 \mathrm{a}$ : Information quality has positive effect on customer trust

$\mathrm{H} 2 \mathrm{~b}$ : Information quality has positive effect on customer satisfaction

Security in online shopping could related with the process of collecting the user's data, capacity and the security of data storage media, and also the payment method (Kolsaker \& Payne, 2002). The perceived security of online transactions has a significant positive influence on customer trust (Bojang, 2017). In addition, people who perceived higher level of security were also more satisfied with the quality of a provided service (Hutinski, 2012). This study establishes the following hypothesis:

H3a: Perceived security has positive effect on customer trust

$\mathrm{H} 3 \mathrm{~b}$ : Perceived security has positive effect on customer satisfaction

Perceived privacy in online business usually connected with information privacy which describe the personal concerns regarding the company's ability to collect their personal information (Castabeda \& Montoro, 2007). The perceived privacy of online transactions has a significant positive influence on customer trust (Bojang, 2017). Privacy is a critical factor in acquiring potential online customers and retaining existing customers (Park \& Kim, 2003). Another study also confirmed that the perceived privacy was found to be the determinants of e-commerce service satisfaction (Eid, 2011; Sadeh et al., 2011). This study establishes the following hypothesis:

H4a: Perceived privacy has positive effect on customer trust

$\mathrm{H} 4 \mathrm{~b}$ : Perceived privacy has positive effect on customer satisfaction

Customer online review is a factor that influence the customer buying intention in online business (Chatterje, 2001). Customer opinions were more influenced by online reviews in the online platform (Flanagin \& Metzger, 2000). In online business when the online buyers give rating to the product positively, that ratings could increase the sales (Forman, Ghose \& Wiesenfeld, 2008). The feedback on e-commerce, including positive and negative ratings, significantly influences customer trust (Ba \& Povlou, 2002) and customer online review affects the customer trust directly (Lee \& Shin, 2011). The online customer review affect customer satisfaction directly (Gupta \& Harris, 2010). This study establishes the following hypothesis:

H5a: Customer online review has positive effect on customer trust

$\mathrm{H} 5 \mathrm{~b}$ : Customer online review has positive effect on customer satisfaction

Trust has a vital influence on consumers activities and thereby on e-commerce success. Online retailers might increase consumer trust and thereby increase the willingness of prospective customers to shop on the internet (Jarvinpaa, Tractinsky \& Vitale, 2000). Trust also defined as a belief that one party can rely on other party and help to develop or maintain the relationship between the parties (Zaltman \& Moorman, 1988). Customer wants to be treated by the same person, especially the service need to clarify the credibility of their staff to make customer more loyal (Bove \& Johnson, 2006). A formalized meetings with customers and giving value to their opinions during meetings make 
INTERNATIONAL JOURNAL OF ACADEMIC RESEARCH IN BUSINESS AND SOCIAL SCIENCES Vol. 10, No. 8, 2020, E-ISSN: 2222-6990 @ 2020 HRMARS

customers more satisfied and ultimately more make them loyal (Ellinger, Dugherty \& Plair, 1999). This study establishes the following hypothesis:

H6: Customer trust has positive effect on customer loyalty

Customer satisfaction is one of the reason why people keep change the preference one of goods or services to another preferences (Fisher, 2001). Another study shows that customer satisfaction is a major factor in determining the loyalty (Anderson \& Srinivasan, 2003). A higher level of customer satisfaction will lead to greater loyalty (Zins, 2001). A consistent purchasing behavior is seen as an indicator of customer loyalty (Mittal \& Kamakurav, 2001; Seiders, Voss \& Godfrey, 2005; Chao, 2008). By that approach there is a greater acceptance that customer loyalty implies repeat purchase behavior and also a positive attitude toward the company (Dick \& Basu, 1994; Oliver, 1999; Chaudhuri \& Holbrook, 2001). This study established the following hypothesis:

H7: Customer satisfaction has positive effect on customer loyalty

Customer loyalty has critical role in a successful of the organization (Flint, Blocker \& Boutin, 2011) and customer loyalty is the main objectives for strategic planning that bring many advantages for the company (Kotler, 2010). In the context of e-commerce, loyal customers are considered extremely valuable. Loyal customer not only require more information themselves, but they serve as an information source for other customer (Vijayalakshmi \& Thyagrajan, 2016).

Customer trust has positive effect on customer satisfaction (Ganesan, 1994), this hypothesis also supported by a researcher, said that customer trust has a significant value on customer satisfaction (Pavlou \& Fygenson, 2006). Other study found that trust is an important factor in customer satisfaction (Gummerus et al., 2004). Mostly, customer trust is important in service sector and also in e-commerce, especially using the technology to have an interaction with customer (Gummerus et al., 2004; Povlou \& Fygenson, 2006). Therefore, this study established the following hypothesis: H8: Customer trust has positive effect on customer satisfaction.

Figure 1. Theoretical Framework

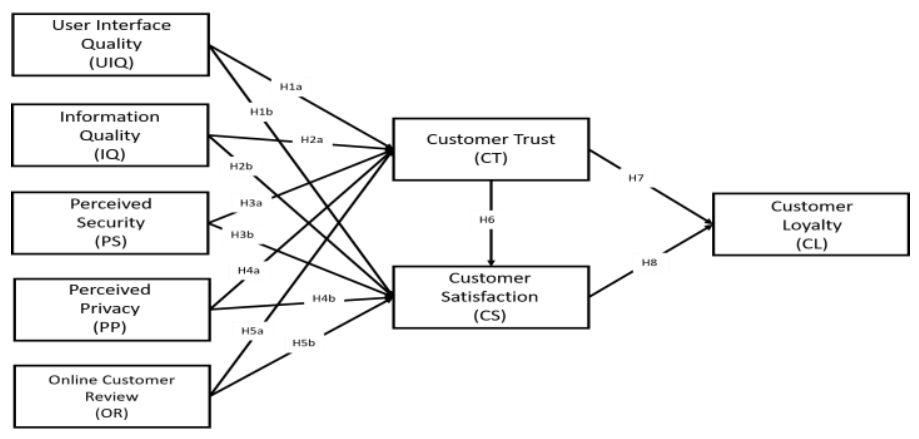

\section{Research Methodology}

In completing this study, a survey questionnaire was conducted among e-commerce customers around Jakarta and Tangerang. The survey was adopted from previous research which reflect to the conceptual framework. The questionnaire consisted of three sections. The first section consist of ecommerce customer demographic, including gender, age, education level, income and occupation. The second section is about e-commerce behavior while doing online shopping. The third section is general question to e-commerce customers. The e-commerce consumer experience were measure by using a set of 32 scale item in the questionnaire, adapted for several previous study with some additional and modification. The questionnaire measure by using Likert scale from (strongly disagree 
INTERNATIONAL JOURNAL OF ACADEMIC RESEARCH IN BUSINESS AND SOCIAL SCIENCES Vol. 10, No. 8, 2020, E-ISSN: 2222-6990 @ 2020 HRMARS

to strongly agree) was used to measure user interface quality, information quality, perceived security, perceived privacy, customer online review, customer trust, customer satisfaction, and customer loyalty.

\section{Result}

The measurement model for all variable were assessed by using Confirmatory Factor Analysis (CFA). Validity and reliability were construct by composite reliability and average variance extracted (AVE). The reliability has a good value when it above 0.7 (Hair et al., 1998) and a study recommended that validity can be assessed by CFA and the recommended value is above 0.5 (Table 1) (Fornell \& Larcker, 1981), the range between 0.612 and 0.919 . The combination of these result shows that the measurement level in a good level of model fit. Composite reliability and average variance extracted for each variable were compute by using formula (Fornell \& Larcker, 1981), as the result the range is between 0.601 and 0.766 .

The respondent of this result is majority from a productive worker with range age between 21 up to 25 years old. In this result, female also dominated as the active online shopper as our respondents, they have range of salary between below 5,000,000 up to 10,000,000, and they spending for online shopping within 3 months are between below 500,000 thousand up to 1,500,000.

Table 1. Confirmatory Factor Analysis

\begin{tabular}{|c|c|c|c|}
\hline $\begin{array}{l}\text { Research } \\
\text { Construct }\end{array}$ & Factor Loading & $\begin{array}{l}\text { Composite } \\
\text { Reliability }\end{array}$ & $\begin{array}{l}\text { Average } \\
\text { Variance }\end{array}$ \\
\hline \multicolumn{2}{|c|}{ User Interface Quality (UI) } & 0.831 & 0.621 \\
\hline UI1 & 0.809 & & \\
\hline UI3 & 0.767 & & \\
\hline UI4 & 0.788 & & \\
\hline \multicolumn{2}{|c|}{ Information Quality (IQ) } & 0.819 & 0.607 \\
\hline IQ1 & 0.612 & & \\
\hline IQ3 & 0.836 & & \\
\hline IQ4 & 0.864 & & \\
\hline \multicolumn{2}{|c|}{ Perceived Security (PS) } & 0.900 & 0.693 \\
\hline PS1 & 0.882 & & \\
\hline PS2 & 0.813 & & \\
\hline PS3 & 0.860 & & \\
\hline PS4 & 0.773 & & \\
\hline \multicolumn{2}{|c|}{ Perceived Privacy (PP) } & 0.854 & 0.661 \\
\hline PP1 & 0.824 & & \\
\hline PP3 & 0.835 & & \\
\hline PP4 & 0.779 & & \\
\hline \multicolumn{2}{|c|}{ Customer Online Review (OR) } & 0.816 & 0.601 \\
\hline OR2 & 0.627 & & \\
\hline OR3 & 0.841 & & \\
\hline OR4 & 0.839 & & \\
\hline \multicolumn{2}{|c|}{ Customer Trust (CT) } & 0.866 & 0.620 \\
\hline CT1 & 0.808 & & \\
\hline $\mathrm{CT} 2$ & 0.829 & & \\
\hline CT3 & 0.860 & & \\
\hline CT4 & 0.632 & & \\
\hline \multicolumn{2}{|c|}{ Customer Satisfaction (CS) } & 0.907 & 0.766 \\
\hline CS1 & 0.860 & & \\
\hline CS2 & 0.919 & & \\
\hline
\end{tabular}


INTERNATIONAL JOURNAL OF ACADEMIC RESEARCH IN BUSINESS AND SOCIAL SCIENCES Vol. 10, No. 8, 2020, E-ISSN: 2222-6990 @ 2020 HRMARS

\begin{tabular}{|c|c|c|c|}
\hline CS3 & 0.844 & & \\
\hline \multicolumn{2}{|c|}{ Customer Loyalty (CL) } & 0.904 & 0.703 \\
\hline CL1 & 0.889 & & \\
\hline $\mathrm{CL2}$ & 0.898 & & \\
\hline CL3 & 0.846 & & \\
\hline CL4 & 0.707 & & \\
\hline
\end{tabular}

The objective of this study is to identify the relationship among user interface quality, information quality, perceived security, perceived privacy, customer online review as a factor affecting the trust and satisfaction of the e-commerce users toward e-loyalty. To aim this objective, SEM used to test the relationship among all variables and to compare the model relationship. Table 2 shows the estimated path coefficients of the structural equation model and the squared multiple correlations (SMC) for dependent latent constructs, which provide an estimate of variance explained. The effects of each of the factors of the user interface quality, information quality, perceived security, perceived privacy, and online review on customer trust are significantly influence customer trust. However, the variables perceived privacy and online on customer trust were not supported.

It has contrast result on customer satisfaction. The results shows that the user interface quality and information quality were significantly influences customer satisfaction. The rest of the variables were not significantly influence customer satisfaction. Also, both customer trust and customer satisfaction on customer trust. Customer trust has no positive effect on customer loyalty, while customer satisfaction has positive effect on customer loyalty. The last result is customer trust has positive effect on customer satisfaction.

Table 2. Path Coefficient

\begin{tabular}{|c|c|c|c|c|}
\hline Hypothesis & Path & Path Coefficient & p-Value & Result \\
\hline $\mathrm{H} 1 \mathrm{a}$ & $\mathrm{UI} \rightarrow \mathrm{CT}$ & 0.346 & 0.000 & Supported \\
\hline $\mathrm{H} 2 \mathrm{a}$ & $\mathrm{IQ} \rightarrow \mathrm{CT}$ & 0.237 & 0.002 & Supported \\
\hline $\mathrm{H} 3 \mathrm{a}$ & $\mathrm{PS} \rightarrow \mathrm{CT}$ & 0.163 & 0.000 & Supported \\
\hline $\mathrm{H} 4 \mathrm{a}$ & $\mathrm{PP} \rightarrow \mathrm{CT}$ & -0.008 & 0.931 & Not Supported \\
\hline $\mathrm{H} 5 \mathrm{a}$ & $\mathrm{OR} \rightarrow \mathrm{CT}$ & 0.006 & 0.932 & Not Supported \\
\hline $\mathrm{H} 1 \mathrm{~b}$ & $\mathrm{UI} \rightarrow \mathrm{CS}$ & 0.229 & 0.000 & Supported \\
\hline $\mathrm{H} 2 \mathrm{~b}$ & $\mathrm{IQ} \rightarrow \mathrm{CS}$ & 0.291 & 0.000 & Supported \\
\hline $\mathrm{H} 3 \mathrm{~b}$ & $\mathrm{PS} \rightarrow \mathrm{CS}$ & 0.129 & 0.056 & Not Supported \\
\hline $\mathrm{H} 4 \mathrm{~b}$ & $\mathrm{PP} \rightarrow \mathrm{CS}$ & -0.007 & 0.907 & Not Supported \\
\hline $\mathrm{H} 5 \mathrm{~b}$ & $\mathrm{OR} \rightarrow \mathrm{CS}$ & 0.075 & 0.134 & Not Supported \\
\hline $\mathrm{H} 6$ & $\mathrm{CT} \rightarrow \mathrm{CL}$ & 0.002 & 0.977 & Not Supported \\
\hline $\mathrm{H} 7$ & $\mathrm{CS} \rightarrow \mathrm{CL}$ & 0.774 & 0.000 & Supported \\
\hline $\mathrm{H} 8$ & $\mathrm{CT} \rightarrow \mathrm{CS}$ & 0.363 & 0.000 & Supported \\
\hline
\end{tabular}


INTERNATIONAL JOURNAL OF ACADEMIC RESEARCH IN BUSINESS AND SOCIAL SCIENCES Vol. 10, No. 8, 2020, E-ISSN: 2222-6990 @ 2020 HRMARS

\section{Discussion}

The result of this research, found that user interface quality and information quality have positive effect both on customer trust and customer satisfaction. User interface quality and information quality are the important factor of customer trust and customer satisfaction in online business, especially in C2C e-commerce platform. This results were supported by Roy, Dewit \& Aubert (2001) who found that user interface quality has direct positive effect on customer trust and McKnight, Choudhury \& Kacmar (2002) argued that the information quality has positive effect on customer trust. Park \& Kim (2003) found that user interface quality and information quality were affect the customer satisfaction directly.

In this research perceived security was found that has a positive effect on customer trust. This result was in line with Bojan (2017) found that the perceived security of online transactions has a significant positive influence on customer trust. This result was contrasted with another hypothesis, which perceived security has no positive effect on customer satisfaction which this finding was not support of the study by Hutinski, 2012). Perceived privacy was found that has no positive effect on both customer trust and customer satisfaction. The other result, we found that there is no positive relationship between customer online reviews has no positive effect for both customer trust and customer satisfaction. Other relationship which is customer trust has no positive effect on customer loyalty, which contrast with the study by Bove \& Johnson (2006) argued that customer wants to be treated by the same person, especially the service need to clarify the credibility of their staff to make customer more loyal. While customer satisfaction has positive effect on customer loyalty. This result was support by Zins (2001) who stated that a higher level of customer satisfaction will lead to greater loyalty.

\section{Conclusion}

In summary, this research confirmed that user interface quality and information quality were important factor on both customer trust and customer satisfaction for e-commerce Shopee. While, perceived security only supported on customer trust and not supported on customer satisfaction. Perceived privacy and online customer review has no effect for both customer trust and customer satisfaction. This research also shown that customer trust has no effect on customer loyalty, while customer satisfaction has positive effect on customer loyalty. This replication research demonstrated the several factors that impact the trust, satisfaction and loyalty on C2C e-commerce Shopee. Adding customer online reviews as the additional variable that we investigated and both customer trust and customer satisfaction were also important factor for online business.

Another result that we found that customer trust has a positive relationship on customer satisfaction. This result was an indirect relationship to the customer satisfaction. As we discuss above, only user interface quality and information quality that has positive relationship on both customer trust and customer satisfaction. While other variable like perceived security has no direct effect on customer loyalty. Therefore, by adding the relationship between customer trust and customer satisfaction.

\section{Limitation and Future Research}

This research has several limitation. The sample of this research mostly the user of $\mathrm{C} 2 \mathrm{C}$ ecommerce Shopee. The sample size we only took about 200 people to test this study. Therefore, to increase the value of this study, future researcher should attempt larger sample size of e-commerce 
INTERNATIONAL JOURNAL OF ACADEMIC RESEARCH IN BUSINESS AND SOCIAL SCIENCES Vol. 10, No. 8, 2020, E-ISSN: 2222-6990 @ 2020 HRMARS

consumers and the scope of this study should be more expand from present study. Future studies are expected to be able to find other variables that affect trust, satisfaction and customer loyalty in e-commerce. In addition, research can also be conducted on non-C2C platforms such as Business to Consumer (B2C) in e-commerce.

The implication of this research is that Shopee must focus on user interface quality and information quality. This is because these two variables have the most influence on customer loyalty. Increasing user interface quality can be done by improving the appearance of Shopee websites to be easier to use, by adding features that make it easier for consumers to search for goods, or make transactions. Information quality can also be improved by providing more complete information about all policies in Shopee, also regarding product features, product size, usability, and so on. In addition, consumer privacy and security must also be maintained to anticipate changes in consumer preferences in the future. Furthermore, online review in this research does not affect customer loyalty, but Shopee should not ignore these variables.

\section{References}

Anderson, R. E., \& Srinivasan, S. S. (2003). E-satisfaction and e-loyalty: A contingency framework. Psychology \& marketing, 20(2), 123-138.

Ba, S., \& Pavlou, P. A. (2002). Evidence of the effect of trust building technology in electronic markets: Price premiums and buyer behavior. MIS quarterly, 243-268.

Barnes, S., \& Vidgen, R. (2000). WebQual: an exploration of website quality. ECIS 2000 proceedings, 74.

Bojang, I. (2017). Determinants oOf Trust in B2c E-Commerce and their Relationship with Consumer Online Trust: A Case of Ekaterinburg, Russian Federation. The Journal of Internet Banking and Commerce, 1-59.

Bove, L. L., \& Johnson, L. W. (2006). Customer loyalty to one service worker: should it be discouraged?. International Journal of Research in Marketing, 23(1), 79-91.

Castañeda, J. A., \& Montoro, F. J. (2007). The effect of Internet general privacy concern on customer behavior. Electronic Commerce Research, 7(2), 117-141.

Chao, P. (2008). Exploring the nature of the relationships between service quality and customer loyalty: an attribute-level analysis. The service industries journal, 28(1), 95-116.

Chatterje, P. (2001). Online Reviews: Do Consumers Use Them? Advance In Consumer Research, 129-133.

Chaudhuri, A., \& Holbrook, M. B. (2001). The chain of effects from brand trust and brand affect to brand performance: the role of brand loyalty. Journal of marketing, 65(2), 81-93.

Coulter, K. S., \& Coulter, R. A. (2002). Determinants of trust in a service provider: the moderating role of length of relationship. Journal of services marketing.

Dick, A. S., \& Basu, K. (1994). Customer loyalty: toward an integrated conceptual framework. Journal of the academy of marketing science, 22(2), 99-113.

Eid, M. I. (2011). Determinants of e-commerce customer satisfaction, trust, and loyalty in Saudi Arabia. Journal of electronic commerce research, 12(1), 78.

Ellinger, A. E., Daugherty, P. J., \& Plair, Q. J. (1999). Customer satisfaction and loyalty in supply chain: the role of communication. Transportation Research Part E: Logistics and Transportation Review, 35(2), 121-134.

Fisher, A. (2001). Winning the battle for customers. Journal of Financial Services Marketing, 6(1), 77-83.

Flanagin, A. J., \& Metzger, M. J. (2000). Perceptions of Internet information credibility. Journalism \& Mass Communication Quarterly, 77(3), 515-540.

Flint, D. J., Blocker, C. P., \& Boutin, J. P. J. (2011). Customer value anticipation, customer satisfaction and loyalty: An empirical examination. Industrial marketing management, 40(2), 219-230.

Floh, A., \& Treiblmaier, H. (2006). What keeps the e-banking customer loyal? A multigroup analysis of the moderating role of consumer characteristics on e-loyalty in the financial service industry. A Multigroup 
INTERNATIONAL JOURNAL OF ACADEMIC RESEARCH IN BUSINESS AND SOCIAL SCIENCES

Vol. 10, No. 8, 2020, E-ISSN: 2222-6990 @ 2020 HRMARS

Analysis of the Moderating Role of Consumer Characteristics on E-Loyalty in the Financial Service Industry.(March 26, 2006).

Forman, C., Ghose, A., \& Wiesenfeld, B. (2008). Examining the relationship between reviews and sales: The role of reviewer identity disclosure in electronic markets. Information systems research, 19(3), 291-313.

Fornell, C., \& Larcker, D. F. (1981). Evaluating structural equation models with unobservable variables and measurement error. Journal of marketing research, 18(1), 39-50.

Ganesan, S. (1994). Determinants of long-term orientation in buyer-seller relationships. Journal of marketing, 58(2), 1-19.

Gretzel, U., Fesenmair, D., Lee, Y., \& Tussyaidiah, I. (2011). Narrating Travel Experience: The Role of Newe Media in R. Sharpley \& P. Stone (Eds). Tourist Experience: Contemporary Perspectives, 171-182.

Gummerus, J., Liljander, V., Pura, M., \& Van Riel, A. (2004). Customer loyalty to content-based Web sites: the case of an online health-care service. Journal of services Marketing.

Gupta, P., \& Harris, J. (2010). How e-WOM recommendations influence product consideration and quality of choice: A motivation to process information perspective. Journal of Business Research, 63(9-10), 10411049.

Hair, J., Anderson, R., Tatham, R., \& Black, W. (1998). Multivariative Data Analysis With Readings. New York: Macmillan.

Hardy, M. (2018). Why Online Reviews Are Important for Your Business. Retrieved from https://www.businessknowhow.com/internet/reviews.htm

Hutinski, R. M. (2012). The Role of Percieved Privacy and Percieved Security in Online Market. 2012 Proceedings of the 35th International Convention MIPRO.

Iprice. (2018). Peta E-Commerce Indonesia. Retrieved from https://iprice.co.id/insights/mapofecommerce/

Jarvenpaa, S. L., Tractinsky, N., \& Vitale, M. (2000). Consumer trust in an Internet store. Information technology and management, 1(1-2), 45-71.

Kim, M., \& Lennon, S. (2008). The effects of visual and verbal information on attitudes and purchase intentions in internet shopping. Psychology \& Marketing, 25(2), 146-178.

Kolsaker, A., \& Payne, C. (2002). Engendering trust in e-commerce: a study of gender-based concerns. Marketing intelligence \& planning.

Kominfo. (2018). Jumlah Pengguna Internet 2017 Meningkat, Kominfo Terus Lakukan Percepatan Pembangunan Broadband. Retrieved from

https://kominfo.go.id/index.php/content/detail/12640/siaran-pers-no-53hmkominfo022018-tentangjumlah-pengguna-internet-2017-meningkat-kominfo-terus-lakukan-percepatan-pembangunanbroadband/0/siaran_pers

Kotler, P. (2010). Marketing Management. Prentice Hall, Inc . New York.

Koufaris, M., \& Hampton-Sosa, W. (2004). The development of initial trust in an online company by new customers. Information \& management, 41(3), 377-397.

Lee, J., \& Shin, H. (2011). The Long Tail or The Short Tail: The Category-Specific Impact of e-WOM on Sales Distribution. Decision Support System, 466-479.

McKnight, D., Choudhury, V., \& Kacmar, C. (2002). Developing and Validating Trust Measures for E-Commerce: An Integrative Typology. Information System Research, 334-359.

Mithas, S., Ramasubbu, N., Krishnan, M., \& Fornell, C. (2006). Designing Web Sites for Customer Loyalty Across Business Domain: A Multilevel Analysis. Journal of Management Information System, 97-127.

MittaL, B., \& Sheth, J. (2004). Customer's Behaviour. A managerial perspective. 2nd ed. Thomson SouthWestern Ohio.

Mittal, V., \& Kamakurav, W. (2001). Satisfaction, Repurchase Intent, and Repurchase Behavior: Investigating The Moderating Effect of Customer Characteristics. Jouornal of Marketing Research, 131-142.

Moses, S. B. (2003). Trust Managment in the Public Key Infrastructure. Retrieved from www.entrust.com/resources/download.cfm/21126/trustmodels. pdf?inline=false 
INTERNATIONAL JOURNAL OF ACADEMIC RESEARCH IN BUSINESS AND SOCIAL SCIENCES

Vol. 10, No. 8, 2020, E-ISSN: 2222-6990 @ 2020 HRMARS

Oliver, R. (1999). Whence Customer Loyalty. Journal Of Marketing, 33-44.

Park, C., \& Kim, Y. (2003). Identifying Key Fators Affecting Consumer Purchase Behavior in An Online Shopping Context. International Journal of Retail \& Distribution Management, 16-29.

Pavlou, P., \& Fygenson, M. (2006). Understanding and Predicting Electronic Commerce Adoption: An Extension of the Theory of Planned Behavior. MIS Quarterly, 115-143.

Reicheld, F., \& Sasser, W. (1990). Zero Defection: Quality Comes to Services. Harvard Business Review, 105111.

Roy, M., Dewit, O., \& Aubert, B. (2001). The Impact of Interface Usability on Trust in Web Retailers. Internet Research: Electronic Networking Application and Policy, 388-398.

Sadeh, S., Sadeh, E., Mousavi, L., \& Asgari, F. (2011). The Effect of Website Quality Dimension on Customer Satisfaction in E-Retailing System. Middle-East Journal of Scientific Research, 366-369.

Seiders, K., Voss, G. D. G., \& Godfrey, A. (2005). Do Satisfied Customers Buy More? Examining Moderating Influences in A Retailing Context. Journal of Marketing, 25-43.

Shoemaker, S., \& Lewis, R. (1999). Customer Loyallty: The Future of Hospitality Marketing. Hospitality Management, 345-370.

Todd, B. W. (2005). A Theoretical Integration of User Satisfaction and Technology Acceptance. Information System Research, 85-102.

Vijayalakshmi, R., \& Thyagrajan, V. (2016). Customer Loyalty Towards Online Retail Stores. International Journal of Advanced Scientific Research \& Development, 9-15.

Yoo, K., \& Gretzel, U. (2008). What Motivates Consumers To Write Online Travel Reviews? Information Technology \& Tourism, 283-295.

Zaltman, G., \& Moorman, C. (1988). The Importance of Personal Trust in The Use of Research. Journal of Advertising Research, 16-24.

Zhang, J. Q., Dixit, A., \& Friedmann, R. (2010). Customer loyalty and lifetime value: an empirical investigation of consumer packaged goods. Journal of marketing theory and practice, 18(2), 127-140.

Zins, A. (2001). Realtives Atittudes and Commitment in Customer Loyalty Models - Some Experience in The Commercial Airline Industry. International Journal of Service Industry Management, 269-294 